\title{
Atomic layer deposition of tin oxide thin films from bis[bis(trimethylsilyl)amino]tin(II) with ozone and water
}

\section{Tupala, Jere Olavi}

2017-05-30

Tupala , J O , Kemell , M L , Mattinen , M J , Meinander , N K , Seppälä , S S , Hatanpää , T T , Räisänen , J A , Ritala , M K \& Leskelä, M A 2017 , ' Atomic layer deposition of tin oxide thin films from bis[bis(trimethylsilyl)amino]tin(II) with ozone and water ' , Journal of Vacuum Science Technology A: Vacuum, Surfaces, and Films , vol. 35 , no. 4 , 041506 . https://doi.org/10.1116/1.4984279

http://hdl.handle.net/10138/307766

https://doi.org/10.1116/1.4984279

unspecified

publishedVersion

Downloaded from Helda, University of Helsinki institutional repository.

This is an electronic reprint of the original article.

This reprint may differ from the original in pagination and typographic detail.

Please cite the original version. 


\section{Atomic layer deposition of tin oxide thin films from bis[bis(trimethylsilyl)amino]tin(II) with ozone and water}

Jere Tupala, Marianna Kemell, and Miika MattinenKristoffer MeinanderSanni Seppälä and Timo HatanpääJyrki RäisänenMikko Ritala and Markku Leskelä

Citation: Journal of Vacuum Science \& Technology A: Vacuum, Surfaces, and Films 35, 041506 (2017); doi: 10.1116/1.4984279

View online: http://dx.doi.org/10.1116/1.4984279

View Table of Contents: http://avs.scitation.org/toc/jva/35/4

Published by the American Vacuum Society

Contact Hiden Analytical for further details: W www.HidenAnalytical.com E info@hiden.co.uk CLICK TO VIEW our product catalogue

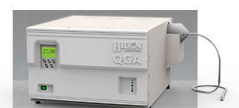

Gas Analysis dynamic measurement of reaction gas streams cataysis and thermal analysis - molecular beam studes dissolved speces probes fermentation, envirormental and ecological stud

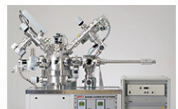

Surface Science UHVTPD

SIMS

, end point detection in in beam etch , elemental imaging-surface mapping

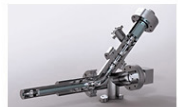

Plasma Diagnostics plasma source characterization etch and deposition process reaction kinetic studies

analysis of neutral and radical species

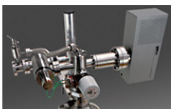

Vacuum Analysis partial pressure measurement and control of process gases reactive sputter process control vacuum diagnostic 


\title{
Atomic layer deposition of tin oxide thin films from bis[bis(trimethylsilyl)amino]tin(II) with ozone and water
}

\author{
Jere Tupala, ${ }^{\text {a) }}$ Marianna Kemell, and Miika Mattinen \\ Department of Chemistry, University of Helsinki, P.O. Box 55, FI-00014, Helsinki, Finland \\ Kristoffer Meinander \\ Division of Materials Physics, Department of Physics, University of Helsinki, P.O. Box 43, FI-00014, Helsinki, \\ Finland
}

Sanni Seppälä and Timo Hatanpää

Department of Chemistry, University of Helsinki, P.O. Box 55, FI-00014, Helsinki, Finland

\begin{abstract}
Jyrki Räisänen
Division of Materials Physics, Department of Physics, University of Helsinki, P.O. Box 43, FI-00014, Helsinki, Finland
\end{abstract}

Mikko Ritala and Markku Leskelä

Department of Chemistry, University of Helsinki, P.O. Box 55, FI-00014, Helsinki, Finland

(Received 22 March 2017; accepted 16 May 2017; published 30 May 2017)

\begin{abstract}
Tin oxide thin films were grown by atomic layer deposition (ALD) from bis[bis(trimethylsilyl) amino]tin(II) with ozone and water. The ALD growth rate of tin oxide films was examined with respect to substrate temperature, precursor doses, and number of ALD cycles. With ozone two ALD windows were observed, between 80 and $100^{\circ} \mathrm{C}$ and between 125 and $200^{\circ} \mathrm{C}$. The films grown on soda lime glass and silicon substrates were uniform across the substrates. With the water process the growth rate at $100-250^{\circ} \mathrm{C}$ was $0.05-0.18 \AA /$ cycle, and with the ozone process, the growth rate at $80-200^{\circ} \mathrm{C}$ was $0.05-0.11 \AA$ /cycle. The films were further studied for composition and morphology. The films deposited with water showed crystallinity with the tetragonal $\mathrm{SnO}$ phase, and annealing in air increased the conductivity of the films while the $\mathrm{SnO}_{2}$ phase appeared. All the films deposited with ozone contained silicon as an impurity and were amorphous and nonconductive both as-deposited and after annealing. The films were further deposited in $\mathrm{TiO}_{2}$ nanotubes aiming to create a pn-junction which was studied by I-V measurements. The $\mathrm{TiO}_{2}$ nanostructure functioned also as a test structure for conformality of the processes. (C) 2017 American Vacuum Society. [http://dx.doi.org/10.1116/1.4984279]
\end{abstract}

\section{INTRODUCTION}

Tin oxides $\left(\mathrm{SnO}_{2} / \mathrm{SnO}\right)$ are widely studied materials with properties such as transparency, conductivity and band gap $(3.6 / 2.7 \mathrm{eV})^{1,2}$ that make them very useful materials to be used as, e.g., transparent electrodes in solar cells ${ }^{3}$ and other optoelectronics components. ${ }^{4}$ Especially, fluorine-doped $\mathrm{SnO}_{2}$ and tin-doped $\mathrm{In}_{2} \mathrm{O}_{3}$ (ITO) are important transparent conductors involving tin oxides. Tin oxides have been used also in gas sensor ${ }^{5}$ and catalytic ${ }^{6}$ applications that are enabled by the characteristic property of tin to change between oxidation states $\mathrm{Sn}^{2+}$ and $\mathrm{Sn}^{4+}$. Other possible uses for tin oxides are in flat panel displays, UV-LEDs, and p-channel thin film transistors. ${ }^{8,9}$

Because complete or partial oxidation of tin(II) to tin(IV) occurs easily, ${ }^{7}$ tin(IV) oxide is more widely studied. Tin oxide thin films have been prepared by spray pyrolysis, ${ }^{10} \mathrm{CVD},{ }^{11}$ sputtering, ${ }^{12,13}$ sol-gel method, ${ }^{14}$ pulsed laser deposition, ${ }^{9}$ electron beam evaporation, ${ }^{15}$ etc., but the recent development of reduction of the feature size in electronic devices has led to the need of controllable and conformal growth methods such as atomic layer deposition (ALD). ${ }^{16}$ ALD has been used to deposit $\mathrm{SnO}_{2}$ films from, e.g., halogenides, ${ }^{17,18}$ amides, ${ }^{19,20}$

${ }^{a}$ Electronic mail: jere.tupala@helsinki.fi alkoxides, ${ }^{21}$ and alkyltin precursors, ${ }^{22,23}$ but to our knowledge, only one precursor, bis(1-dimethylamino-2-methyl-2-propoxy) tin(II), ${ }^{24}$ has so far been presented to deposit SnO by ALD. The oxygen source in the $\mathrm{SnO}$ process was water. Besides water $^{25}$ and ozone, ${ }^{26}$ the most common oxygen sources for $\mathrm{SnO}_{2}$ are $\mathrm{O}_{2}$ (Refs. 17 and 18) and hydrogen peroxide ${ }^{19,20}$ but also carboxylic acid ${ }^{21}$ and $\mathrm{NO}_{\mathrm{x}}$ (Ref. 26) have been used. In addition to these thermal ALD processes, $\mathrm{SnO}_{\mathrm{x}}$ has also been deposited with plasma enhanced ALD. ${ }^{27-29}$

In the present work, we deposited $\mathrm{SnO}$ and $\mathrm{SnO}_{2}$ on silicon and glass substrates by ALD using a novel precursor bis[bis(trimethylsilyl)amino]tin(II), $\quad\left[\left[\left(\mathrm{CH}_{3}\right)_{3} \mathrm{Si}\right]_{2} \mathrm{~N}\right]_{2} \mathrm{Sn}$. Water or ozone were used as oxygen sources. These novel ALD processes were further used to create coaxial nanotubes by growing tin oxide in nanotubular $\mathrm{TiO}_{2}$ structures to test the electrical properties of the films and conformality of the processes.

\section{EXPERIMENT}

\section{A. Film growth}

Tin oxide films were grown on $5 \times 5 \mathrm{~cm}^{2}$ silicon (100) and soda lime glass substrates using the atomic layer deposition method. Some test samples were also deposited on $3 \times$ 
$4 \mathrm{~cm}^{2}$ nanotubular $\mathrm{TiO}_{2} / \mathrm{ITO}$ structures that were made in accordance with our previous study. ${ }^{30}$ The tin precursor was bis[bis(trimethylsilyl)amino]tin(II) (Aldrich), and ozone or water was used as the oxygen source. Films were grown in the F120 ALD reactor (ASM Microchemistry, Ltd., Finland), and nitrogen (99.9995\%, $\mathrm{H}_{2} \mathrm{O}<3 \mathrm{ppm}, \mathrm{O}_{2}<3 \mathrm{ppm}$ ) was used as carrier and purging gas. Water was pulsed into the reactor through a needle valve and a solenoid valve from an external source held at room temperature, and was transported further in the reactor with nitrogen. Ozone was produced with a Wedeco Ozomatic Modular 4 HC Lab ozone generator from oxygen $(99.999 \%)$ and pulsed into the reactor through a needle valve and a solenoid valve from the main ozone flow line. The estimated ozone concentration output of the generator was about $100 \mathrm{~g} / \mathrm{N} \mathrm{m}^{3}$ with a flow rate of $30 \mathrm{l} / \mathrm{h}$. The Sn precursor was sublimed from an open boat held inside the reactor at $62^{\circ} \mathrm{C}$ and pulsed with inert gas valving. The pressure inside the reactor during the deposition cycle was about 10 mbar. The deposition temperature range was from 100 to $250{ }^{\circ} \mathrm{C}$ for the water process and $80-200{ }^{\circ} \mathrm{C}$ for the ozone process, while at higher temperatures, no film growth was observed. Pulses for both precursors were varied from $0.5 \mathrm{~s}$ up to $5.0 \mathrm{~s}$ while the nitrogen purge was varied between 2.0 and $10.0 \mathrm{~s}$. After the deposition, some samples were annealed at $500{ }^{\circ} \mathrm{C}$ in air for $6 \mathrm{~h}$ to affect the crystallinity and conductivity of the films.
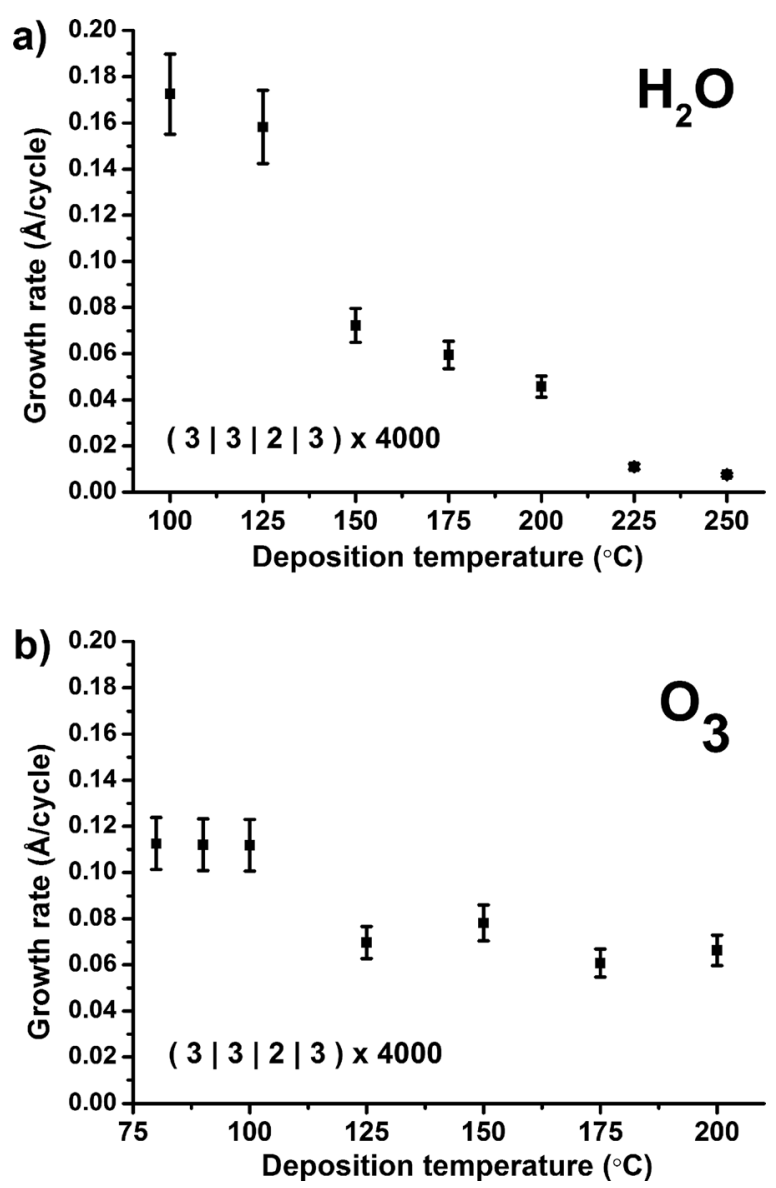

FIG. 1. Growth rates of the films as a function of deposition temperature. The films were grown for 4000 cycles, and the precursor pulse lengths for metal was $3.0 \mathrm{~s}$ and for oxygen source $2.0 \mathrm{~s}$. (a) Water and (b) ozone.

\section{B. Characterization}

The surface morphologies of the films were studied with a Hitachi S-4800 field emission scanning electron microscope (FESEM). Crystallinities and thicknesses of the films were studied by a PANalytical X'Pert PRO MPD x-ray diffractometer. The measured thicknesses were confirmed with Oxford INCA 350 energy dispersive x-ray microanalysis system (EDS) connected to the Hitachi FESEM. The error bars in Figs. $1-3$ are $\pm 10 \%$ of the measured values which is the estimated error in our EDS measurements. The thicknesses were calculated from the $\mathrm{k}$ ratios of $\mathrm{SnL} \alpha$ lines using a GMRFILM program. ${ }^{31}$ Stoichiometry of $\mathrm{SnO}$ (with water) or $\mathrm{SnO}_{2}$ (with ozone) and density of $6.0 \mathrm{~g} / \mathrm{cm}^{3}$ were assumed in the calculations, thus taking into account the lower density of the ALD grown films with low crystallinity.
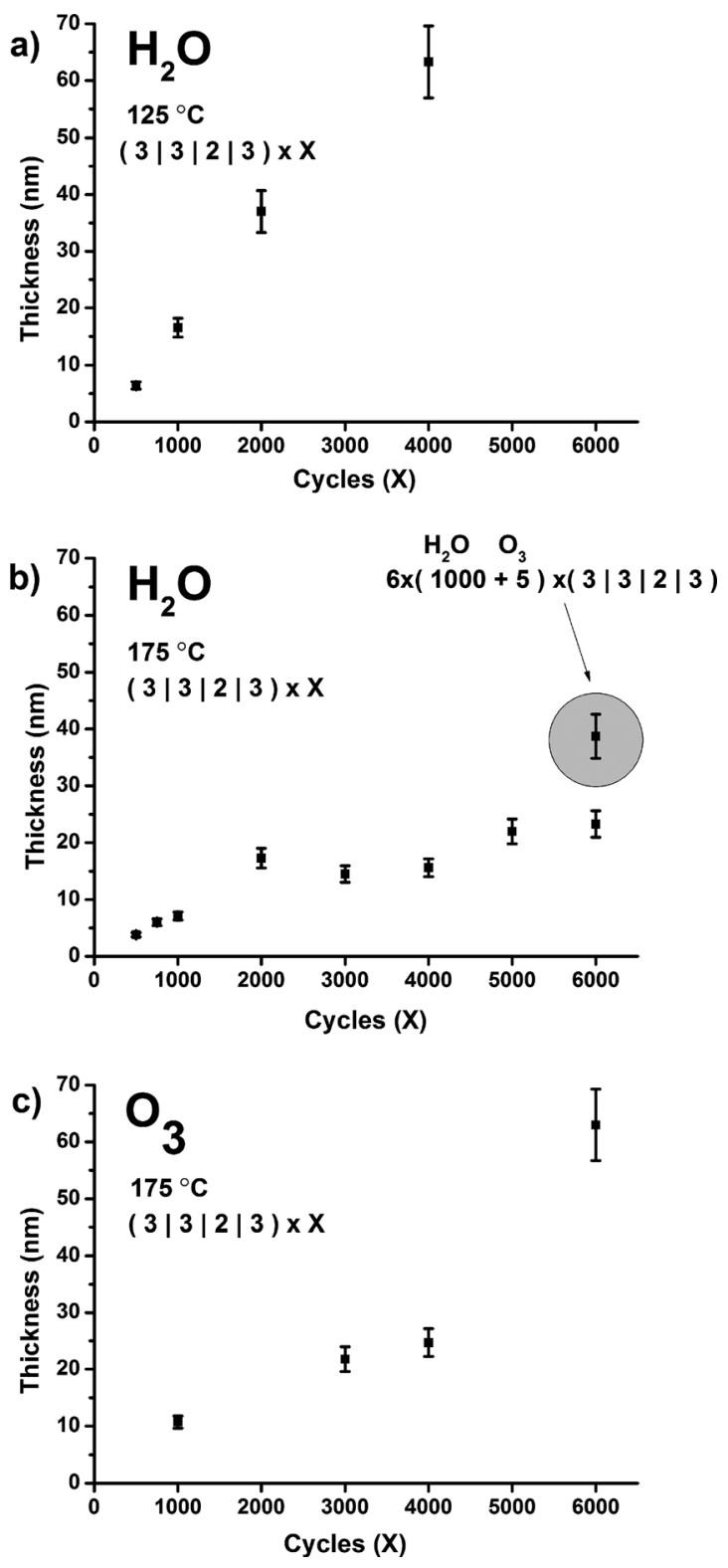

FIG. 2. Thicknesses of the tin oxide films as a function of number of deposition cycles. Tin monoxide films deposited at (a) $125^{\circ} \mathrm{C}$ and (b) $175^{\circ} \mathrm{C}$, and (c) tin dioxide films deposited at $175^{\circ} \mathrm{C}$. Pulse lengths for metal precursors were $3.0 \mathrm{~s}$ and for water and ozone $2.0 \mathrm{~s}$. 

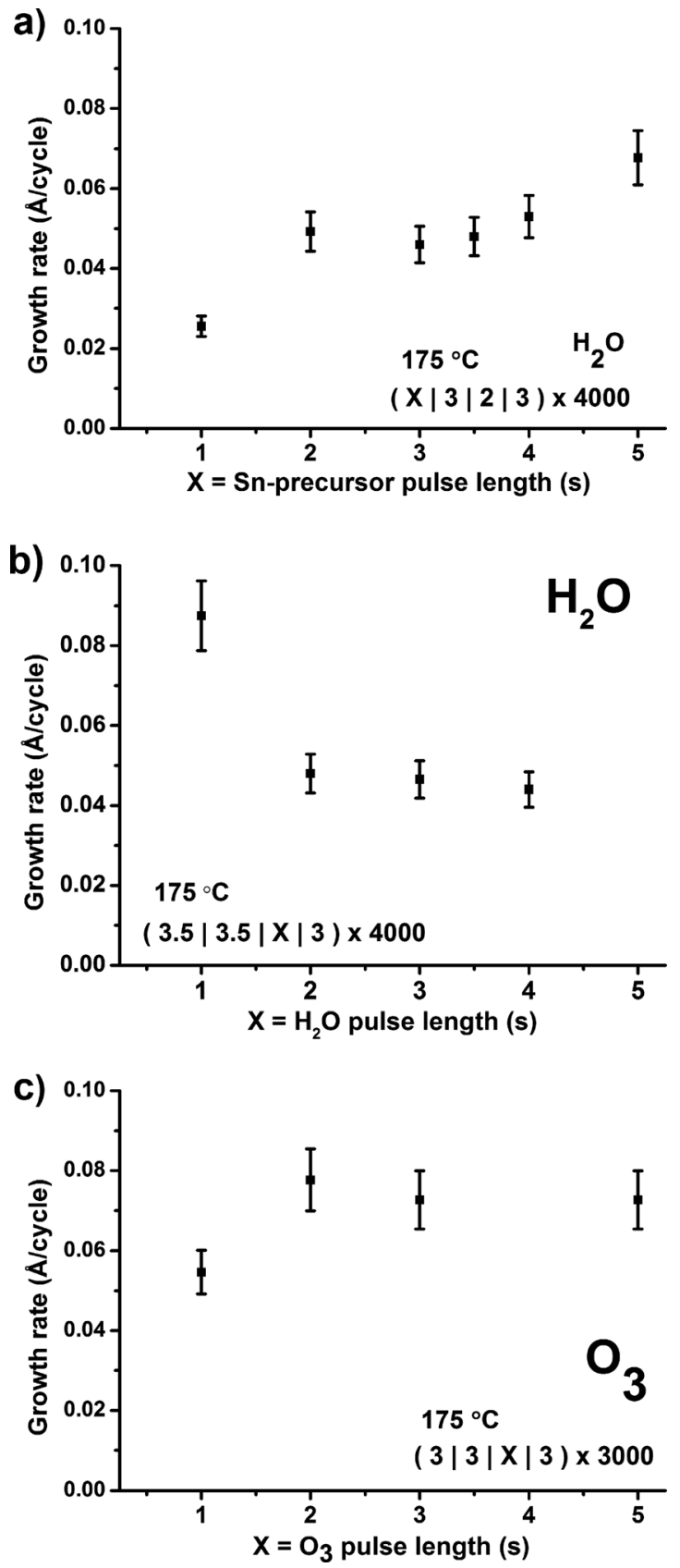

FIG. 3. Growth rates of tin oxide as a function of (a) bis[bis(trimethylsilyl) amino]tin(II) pulse length, (b) water pulse length, and (c) ozone pulse length. All depositions at $175^{\circ} \mathrm{C}$.

UV-vis transmission spectra for band gap determination were measured with a Hitachi U-2000 spectrophotometer. The band gap determination was done according to the literature. $^{32,33}$ The surface resistance measurements were done using a Keithley 2400 Source Meter and an Alessi C4S four point probe head. For I-V measurements, gold dots were evaporated on the nanotubular $\mathrm{TiO}_{2}$ surface through a shadow mask, and the backside of the structure was contacted by using gallium-indium eutectic (Sigma-Aldrich). The I-V measurements were done with the Keithley 2400 Source Meter using a source step delay of $0.01 \mathrm{~s}$ and a step width of $0.1 \mathrm{~V}$. The I-V measurements were done in dark and irradiated with a commercial $50 \mathrm{~W}$ halogen lamp with irradiance of $600 \mathrm{~W} / \mathrm{m}^{2}$.

Atomic force microscopy (AFM) images for analyzing surface roughness and morphology were recorded using Veeco Multimode V AFM with Nanoscope V controller. Images were captured in tapping mode (intermittent contact mode) in air using silicon probes with a nominal tip radius of $6 \mathrm{~nm}$ and a nominal spring constant of $40 \mathrm{~N} / \mathrm{m}$ (ACTA-3 from AppNano). Images were flattened or planefitted to remove artifacts caused by sample tilt and scanner bow. Roughness was calculated as a root-mean-square value (RMS or $\mathrm{Rq})$ from $2 \times 2 \mu \mathrm{m}^{2}$ images $(512 \times 512$ pixels $)$ obtained at $1 \mathrm{~Hz}$ scan rate. Image processing and analysis were done using Bruker Nanoscope Analysis 1.5 program.

The composition of the surface layers was analyzed by x-ray photoelectron spectroscopy (XPS), using an Argus Spectrometer (Omicron NanoTechnology GmbH, Taunusstein, Germany) operating at a pass energy of $20 \mathrm{eV}$. Samples were illuminated with X-rays emitted from a standard $\mathrm{Mg}$ source ( $\mathrm{K} \alpha$ line) at a photon energy of $1253.6 \mathrm{eV}$. Binding energies were calibrated using the $\mathrm{C} 1 \mathrm{~s}$ peak $(284.8 \mathrm{eV})$ of ambient hydrocarbons, and peak fitting was done using the CASAXPS software (www.casaxps.com). Sn $3 \mathrm{~d}_{5 / 2}$ energies of 485.6 and $486.7 \mathrm{eV}$ were matched to $\mathrm{Sn}^{2+}$ and $\mathrm{Sn}^{4+}$ chemical states, respectively, based on the values previously reported in the literature. $^{34}$

\section{RESULTS AND DISCUSSION}

\section{A. Growth rates}

Figures 1(a) and 1(b) show the film growth rates as a function of the deposition temperature while using water and ozone as the oxygen sources. As will be shown later, the films grown with water as the oxygen source are mostly $\mathrm{SnO}$, and the films grown with ozone consist of a mixture of $\mathrm{SnO}_{2}$ and $\mathrm{SiO}_{2}$. With water, the growth rate slows down with increasing temperature. With ozone, the growth rate remains constant at $80-100{ }^{\circ} \mathrm{C}$ and at $125-200{ }^{\circ} \mathrm{C}$, i.e., the so called ALD windows are observed, but the reason of these two levels of growth rates is unknown.

Film thicknesses as a function of the number of deposition cycles are seen in Fig. 2. With water as the oxygen source, the growth is linear at $125^{\circ} \mathrm{C}$ [Fig. 2(a)], but at $175^{\circ} \mathrm{C}$, the film growth starts to slow down after 2000 cycles [Fig. 2(b)]. The slow growth is likely caused by bis(trimethylsilyl)amine [hexamethyldisilazane (HMDS)] that is the expected reaction byproduct in the ALD process with water [Eq. (1)]. HMDS can react with $\mathrm{Sn}-\mathrm{OH}$ and silanol groups on the surface [Eq. (2)] creating $-\mathrm{O}-\mathrm{Si}\left(\mathrm{CH}_{3}\right)_{3}$ groups that do not react with water and hinder the adsorption of tin precursor, thereby decreasing the growth rate

$$
\begin{gathered}
{\left[\left[\left(\mathrm{CH}_{3}\right)_{3} \mathrm{Si}\right]_{2} \mathrm{~N}\right]_{2} \mathrm{Sn}+\mathrm{H}_{2} \mathrm{O} \rightarrow \mathrm{SnO}+2\left[\left(\mathrm{CH}_{3}\right)_{3} \mathrm{Si}\right]_{2} \mathrm{NH},} \\
{\left[\left(\mathrm{CH}_{3}\right)_{3} \mathrm{Si}\right]_{2} \mathrm{NH}+2-\mathrm{OH} \rightarrow 2-\mathrm{O}-\mathrm{Si}\left(\mathrm{CH}_{3}\right)_{3}+\mathrm{NH}_{3} .}
\end{gathered}
$$


Crowe and Tolbert observed in their study that the silica passivation efficiency of HMDS increases with increasing temperature $\left(25-280^{\circ} \mathrm{C}\right) .^{35}$ That would explain why the $\mathrm{SnO}$ films deposited with water at $125^{\circ} \mathrm{C}$ [Fig. 2(a)] are thicker and grow more linearly than the films deposited at $175^{\circ} \mathrm{C}$ [Fig. 2(b)]. With ozone [Fig. 2(c)], the film growth rate does not decrease with increasing number of cycles at $175^{\circ} \mathrm{C}$. Likely ozone oxidizes the surface passivating - $\mathrm{O}-\mathrm{Si}\left(\mathrm{CH}_{3}\right)_{3}$ groups, creating - $\mathrm{Sn}-\mathrm{Si}-\mathrm{O}$ that incorporates silicon oxide in the film, as will be seen later. Nevertheless, the deposition rate with ozone as oxygen source is very low as is the case with water, $0.06-0.09 \AA /$ cycle. To test the hypothesis of the surface passivation by HMDS, a total of 6000 cycles was deposited so that every 1000 cycles of the water process were followed by 5 cycles of the ozone process, resulting in increased thickness [highlighted in Fig. 2(b)] compared to the water process only. It is therefore likely that in the water process the HMDS passivates the growing $\mathrm{SnO}_{\mathrm{x}}$ film surface with $-\mathrm{O}-\mathrm{Si}\left(\mathrm{CH}_{3}\right)_{3}$ groups, especially at elevated temperatures, and hinders the adsorption of $\left[\left[\left(\mathrm{CH}_{3}\right)_{3} \mathrm{Si}\right]_{2} \mathrm{~N}\right]_{2} \mathrm{Sn}$ during the tin precursor pulse [Fig. 1(a)].

The growth rate of the film as a function of the precursor pulse times is seen in Fig. 3. As a function of the tin precursor pulse time [Fig. 3(a)], the growth rate remains the same from 2 to $4 \mathrm{~s}$. The growth rate as a function of the both oxygen precursor pulse lengths, water [Fig. 3(b)] and ozone [Fig. 3(c)], saturates at $2 \mathrm{~s}$ pulse, therefore confirming the self-limiting ALD behavior. In Fig. 3(b), the film growth rate at $1 \mathrm{~s}$ pulse is high although the pulse is short. A possible explanation is that with short $\mathrm{H}_{2} \mathrm{O}$ pulses, the effect of HMDS remains lower as there is not enough water to react with the tin precursor to produce HMDS, and for it to poison the surface completely.

\section{B. Film properties}

The films grown with water were yellow and transparent, while the films deposited with ozone were colorless. All the as-deposited films were nonconductive as studied with fourpoint probe. XRD from the films grown with water showed the presence of crystalline $\mathrm{SnO}$ phase when deposited at $125-175^{\circ} \mathrm{C}$, while the films deposited at lower temperatures

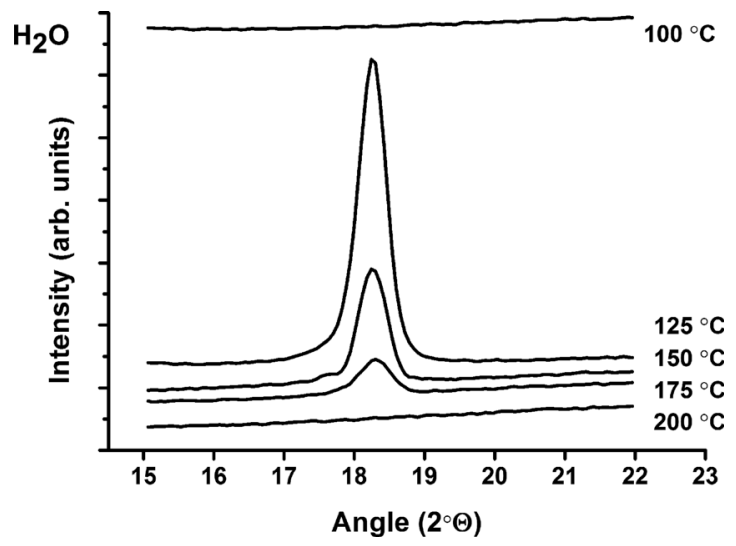

FIG. 4. X-ray diffractograms of the films deposited at $100-200^{\circ} \mathrm{C}$ on glass with water. were amorphous (Fig. 4). The intensity variations in the XRD patterns between the films grown at $125-200^{\circ} \mathrm{C}$ are likely a consequence of thickness difference between the films, but some effect can also arise from impurities in the films that will be discussed later. Tetragonal SnO peak of the as-deposited films disappears, and $\mathrm{SnO}_{2}$ peaks appear when the films grown with water are annealed in air at $500{ }^{\circ} \mathrm{C}$ [Figs. 5(a) and 5(b)]. Also, annealing decreases the resistivity of these films $(45 \mathrm{~m} \Omega \mathrm{cm})$ and the yellow color disappears. When ozone is used, all the as-deposited films are amorphous [Fig. 5(c)]. Annealing in air at $500{ }^{\circ} \mathrm{C}$ for $6 \mathrm{~h}$ does not affect the crystallinity [Fig. 5(d)] or conductivity of the films grown with the ozone process. This behavior is explained by silicon incorporated in the film (13\%-17\%) that is almost equal to the amount of tin (18\%-19\%). Therefore, the film grown with ozone process is not pure $\mathrm{SnO}_{2}$ and annealing does not lead to conductive $\mathrm{SnO}_{2}$ and the films remain amorphous. This is further discussed in the XPS results.

In addition to thickness, the growth temperature has an effect on the surface morphology of the films. FESEM images show that the films grown with the water process at $100-125^{\circ} \mathrm{C}$ (not shown) are smooth, but above $150^{\circ} \mathrm{C}$ [Fig. 6(a)], some grainy character is found on the surface of the films. Especially with water as the oxygen source, small platelets emerge on the surface at $175^{\circ} \mathrm{C}$ [Fig. 6(b)]. On the contrary, the film grown at $200^{\circ} \mathrm{C}$ with water is smoother [Fig. 6(c)]. The films grown with ozone show no grains at $100-125^{\circ} \mathrm{C}$ and contain very small grains at $150-200^{\circ} \mathrm{C}$ [Figs. 6(d) and 6(f)]. Annealing does not affect the morphology of the films.

AFM measurements (Fig. 7) show the same result as the SEM images for the films grown with water: the films grown at $150^{\circ} \mathrm{C}$ are much rougher than the films grown at lower temperatures. The features on the surface are grains rather than separate particles. The grains show large variation in their size, about $30-150 \mathrm{~nm}$ laterally and $2-15 \mathrm{~nm}$ in height. At $175^{\circ} \mathrm{C}$, the roughness is clearly still increasing and some of the features have faceted shape which implies that they are crystalline with some amorphous region in between. The size

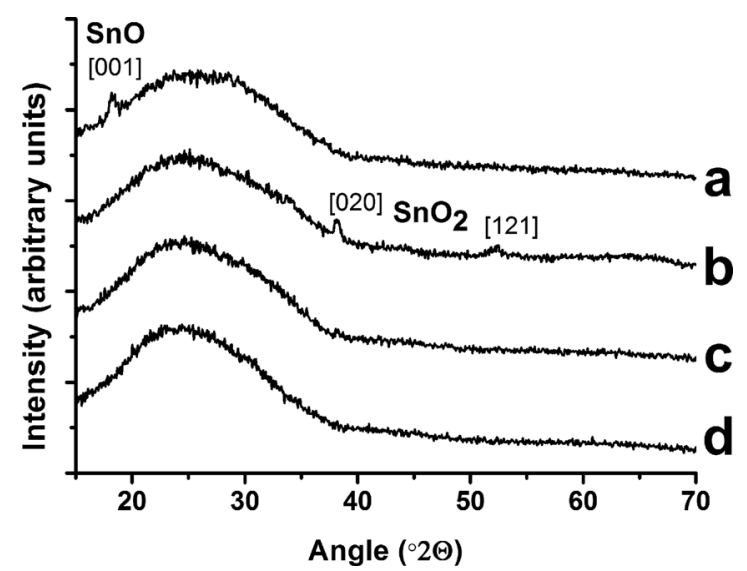

FIG. 5. X-ray diffractograms of the films deposited on glass with water (a) as-deposited at $175^{\circ} \mathrm{C}$ and (b) annealed in air at $500^{\circ} \mathrm{C}$, and of films deposited with ozone (c) as-deposited at $175^{\circ} \mathrm{C}$ and (d) annealed in air at $500^{\circ} \mathrm{C}$. 


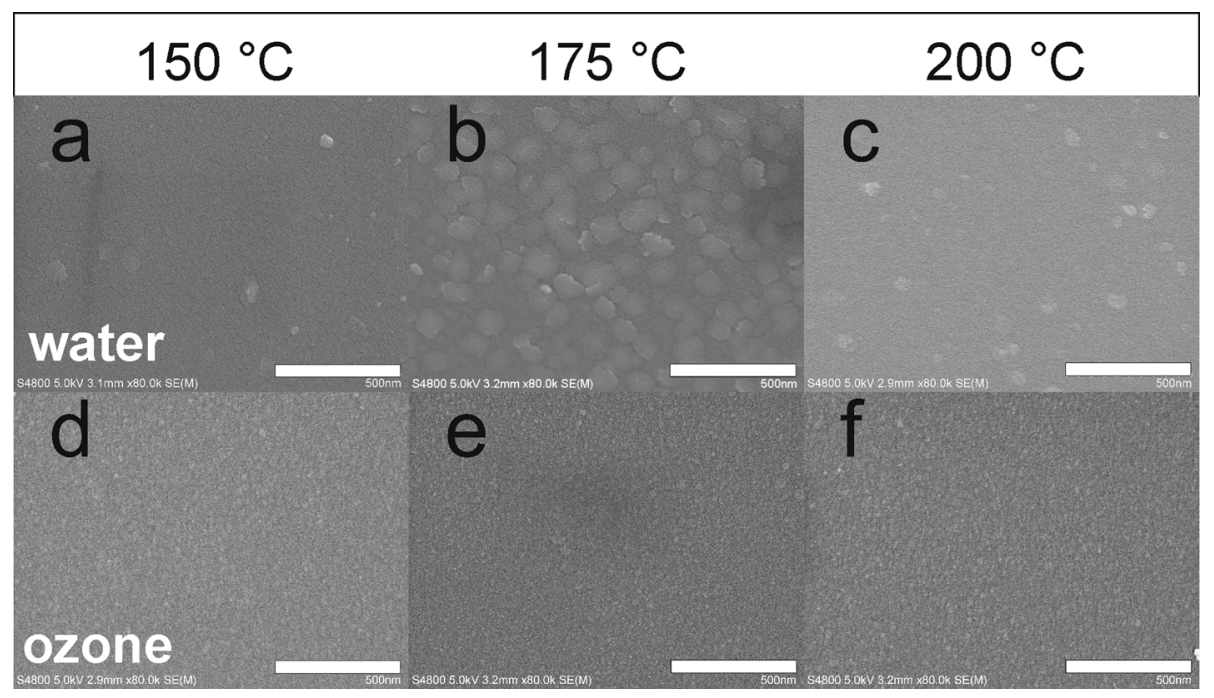

FIG. 6. FESEM images of the films deposited (a)-(c) with water and (d)-(f) with ozone at $150-200^{\circ} \mathrm{C}$. All films were deposited for 4000 cycles. The length of the scale bar is $500 \mathrm{~nm}$ for all images.

varies laterally $100-150 \mathrm{~nm}$ and vertically $5-20 \mathrm{~nm}$; thus, many of the grains can extend through the film. Suprisingly, the films grown with water at $200^{\circ} \mathrm{C}$ are less rough compared to the films deposited at $150-175^{\circ} \mathrm{C}$. At this temperature, only a few grains are visible although they are still homogeneously distributed. The RMS surface roughness of the films grown with water at $100-200^{\circ} \mathrm{C}$ varies between 0.5 and $1.5 \mathrm{~nm}$, and except at $175^{\circ} \mathrm{C}$, the roughness is $2.9 \mathrm{~nm}$. When the films are grown at $175^{\circ} \mathrm{C}$, higher precursor doses and increasing number of cycles seem to lead to larger grains on the surface, increasing the surface roughness. The film thicknesses and roughnesses are presented in Table I. According to AFM measurements (Fig. 7), the amorphous films grown with ozone are all smooth independent of deposition temperature, number of cycles, and precursor dose. The surface roughness with the ozone process varies between 0.6 and $1.3 \mathrm{~nm}$.

Aarik et al. reported a strong effect of crystallization on the deposition rate and roughness of $\mathrm{TiO}_{2}$ films. ${ }^{36}$ They observed that in the $\mathrm{TiCl}_{4} / \mathrm{H}_{2} \mathrm{O}$ process, the film roughness increases with increasing growth rate. This was reported to be an effect of crystallization and the fact that the crystalline anatase phase grows faster than amorphous $\mathrm{TiO}_{2}$. Here, the films grown with water start to roughen at $150^{\circ} \mathrm{C}$ (Fig. 7). But unlike the case in Aarik's study, the film growth rate decreases dramatically at this temperature compared to the smooth films deposited with water at lower temperatures of $100-125^{\circ} \mathrm{C}$ [Fig. 1(a)]. Despite XRD (Fig. 4) showing that the $\mathrm{SnO}$ films grown with water process at $125^{\circ} \mathrm{C}$ are crystalline, they do not show grains on the film surface in AFM. It seems that the onset of roughening and the significant decrease in growth rate take place at the same time while the crystalline character does not increase (Fig. 4). XPS results (Table II) also show that increasing deposition temperature increases the silicon content in the films. It may be that the silicon in the film that is due to HDMS reacting with the surface $-\mathrm{OH}$ affects the crystallization of the films deposited also with the water process. Thus, the higher the deposition temperature, the more silicon, the thinner the film and the less crystallinity.

Figure 8 presents the XPS spectra of the Sn $3 d$ lines of asdeposited tin oxide thin films. Main peaks are comparable to

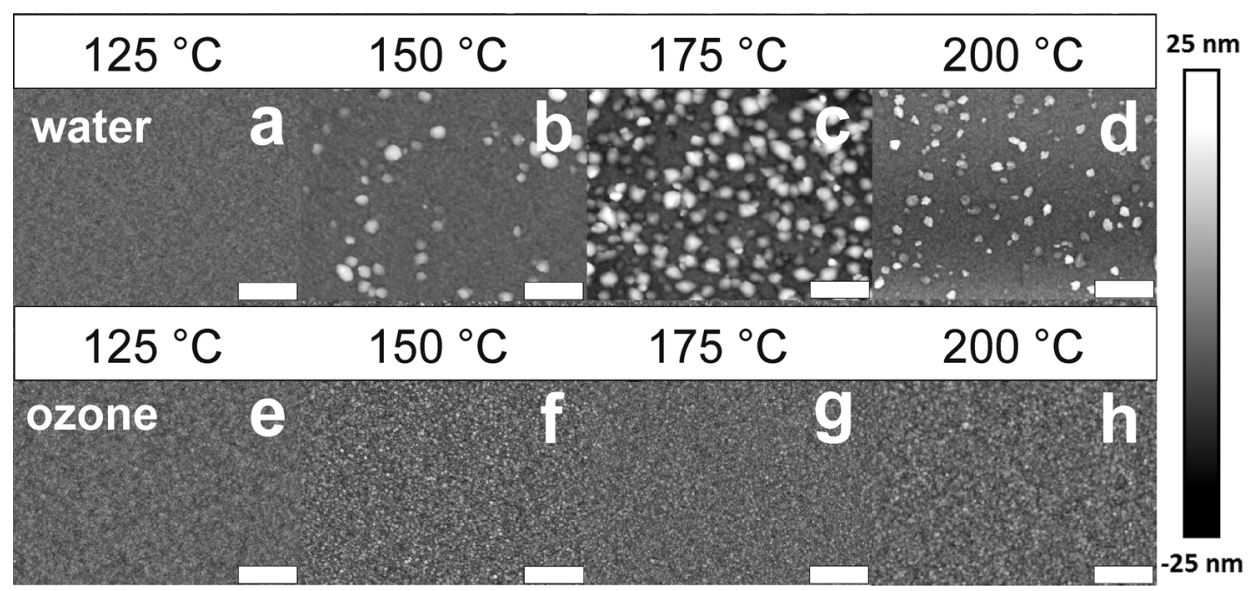

FIG. 7. AFM images of thin films grown (a)-(d) with water and (e)-(h) with ozone. All films deposited for 4000 cycles. Scale bar is $400 \mathrm{~nm}$ in all images. 
TABLE I. Thicknesses and roughnesses $\left(R_{q}\right)$ of the films deposited with water and ozone processes for 4000 cycles in various temperatures. All values in nanometers $(\mathrm{nm})$.

\begin{tabular}{lcccccc}
\hline \hline Precursor & & $100{ }^{\circ} \mathrm{C}$ & $125^{\circ} \mathrm{C}$ & $150{ }^{\circ} \mathrm{C}$ & $175^{\circ} \mathrm{C}$ & $200{ }^{\circ} \mathrm{C}$ \\
\hline \multirow{2}{*}{ Water } & Thickness & 69 & 63 & 24 & 18 & 11 \\
& Roughness & 0.5 & 0.5 & 1.3 & 2.9 & 0.6 \\
\multirow{3}{*}{ Ozone } & Thickness & 45 & 28 & 31 & 25 & 27 \\
& Roughness & 0.6 & 0.9 & 1.3 & 1.1 & 1.0 \\
\hline \hline
\end{tabular}

the data given in the study of Xia et al. ${ }^{34}$ and NIST database: ${ }^{37}$ binding energies of $\mathrm{Sn}^{2+}$ at $485.6 \mathrm{eV}\left(\mathrm{d}_{5 / 2}\right)$ and $494.0 \mathrm{eV}\left(\mathrm{d}_{3 / 2}\right)$, and binding energies of $\mathrm{Sn}^{4+}$ at $486.7 \mathrm{eV}$ $\left(\mathrm{d}_{5 / 2}\right)$ and $495.4 \mathrm{eV}\left(\mathrm{d}_{3 / 2}\right)$, respectively. The measured surface compositions of the thin films are represented in Table II. The XPS measurements show that the films grown with water mostly contain $\mathrm{SnO}$ but also some $\mathrm{SnO}_{2}$ (about 20\%). They also have small quantities (1-3 at. \%) of silicon as an impurity. The films grown with ozone have tin as $\mathrm{SnO}_{2}$, but they have large quantities (13-16 at. \%) of silicon coming from the precursor. The high silicon content in the films grown with ozone process must come from the ligands or $-\mathrm{O}-\mathrm{Si}\left(\mathrm{CH}_{3}\right)_{3}$ surface groups which then are oxidized by ozone. $\mathrm{SnO}_{2}$ and silicon impurities form tin silicate in the film, as can be seen in XPS [Fig. 9(a)]. Nevertheless the high silicon content explains the nonconductivity and amorphous structure of the $\mathrm{SnO}_{2}$ films. Small (0.3-0.7 at. \%) nitrogen impurities [Fig. 9(b)] come from the precursor. Carbon impurities are at the same level as normal surface contamination, and their dependency on the deposition parameters cannot be verified. One tin oxide film was deposited on an aluminum oxide film (Table II) to test if the surface of the substrate has an effect on the deposition. No quantifiable effect was detected.

The XPS results (Fig. 8) show that the films grown with the water process contain some $\mathrm{SnO}_{2}$ character. This can be explained by reaction where water oxidizes $\mathrm{SnO}$ further to $\mathrm{SnO}_{2}$ [Eq. (3)]. Also, it is possible that during deposition, the surface of the growing $\mathrm{SnO}$ film partly disproportionates to $\mathrm{SnO}_{2}$ and $\mathrm{Sn}$ [Eq. (4)]. This reaction has been reported to take place when $\mathrm{SnO}$ films are annealed even in inert atmosphere like nitrogen. ${ }^{7,38}$ During the water pulse, hot water vapor can reoxidize the $\mathrm{Sn}$ to $\mathrm{SnO}$ [Eq. (5)]. At the deposition temperatures of $100-250{ }^{\circ} \mathrm{C}$, Gibbs energies

TABLE II. Elemental compositions and impurities of the films grown with water and ozone as analyzed by XPS. The thickness of $\mathrm{Al}_{2} \mathrm{O}_{3}$ was $75 \mathrm{~nm}$.

\begin{tabular}{lccccc}
\hline \hline Sample & $\mathrm{A}(18 \mathrm{~nm})$ & $\mathrm{B}(69 \mathrm{~nm})$ & $\mathrm{C}(25 \mathrm{~nm})$ & $\begin{array}{c}\mathrm{D}(25 \mathrm{~nm} \\
\left.\text { on } \mathrm{Al}_{2} \mathrm{O}_{3}\right)\end{array}$ & $\mathrm{E}(28 \mathrm{~nm})$ \\
\hline Precursor & Water & Water & Ozone & Ozone & Ozone \\
$\mathrm{T}($ deposition $)$ & $175^{\circ} \mathrm{C}$ & $125^{\circ} \mathrm{C}$ & $175^{\circ} \mathrm{C}$ & $175^{\circ} \mathrm{C}$ & $125^{\circ} \mathrm{C}$ \\
Sn at. \% & 28.8 & 32.7 & 18.0 & 18.2 & 18.9 \\
$\mathrm{O}$ at. \% & 42.9 & 44.6 & 45.1 & 46.1 & 39.8 \\
$\mathrm{C}$ at. \% & 25.1 & 21.2 & 20.3 & 19.0 & 27.4 \\
$\mathrm{Si}$ at. \% & 2.9 & 1.2 & 16.1 & 16.9 & 13.6 \\
$\mathrm{~N}$ at. \% & 0.3 & 0.4 & 0.6 & 0.7 & 0.3 \\
\hline \hline
\end{tabular}
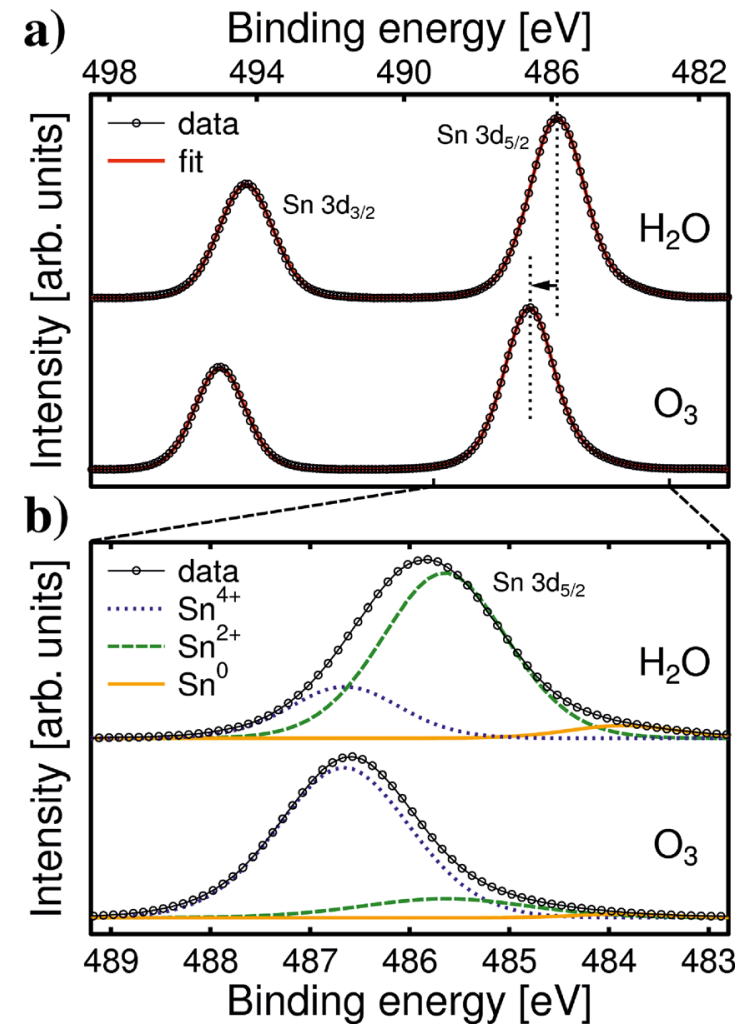

FIG. 8. (Color online) XPS spectra of $\mathrm{Sn} 3 \mathrm{~d}$ for as-deposited films grown with water and ozone. Both depositions at $175^{\circ} \mathrm{C}$.

$\Delta \mathrm{G}$ are negative for Eqs. (3)-(5), ${ }^{39}$ and so, the reactions are favorable

$$
\begin{aligned}
& \mathrm{SnO}+\mathrm{H}_{2} \mathrm{O} \rightarrow \mathrm{SnO}_{2}+\mathrm{H}_{2}, \\
& 2 \mathrm{SnO} \rightarrow \mathrm{Sn}+\mathrm{SnO}_{2}, \\
& \mathrm{Sn}+\mathrm{H}_{2} \mathrm{O} \rightarrow \mathrm{SnO}+\mathrm{H}_{2} .
\end{aligned}
$$

The transmission spectra of the soda lime glass substrate and the films grown with water at different temperatures are shown in Fig. 10. These spectra were used to calculate band gap values for the deposited films. The films grown with

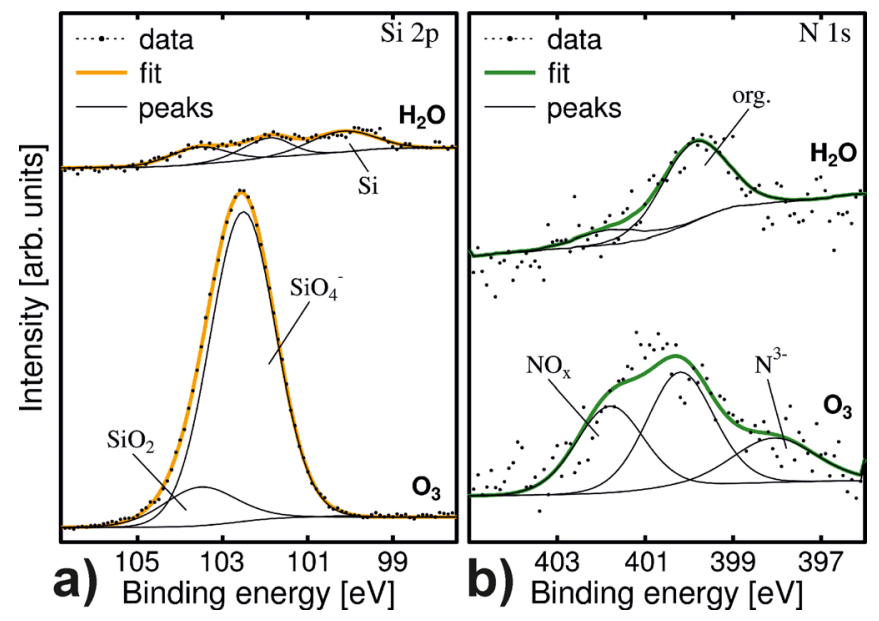

FIG. 9. (Color online) XPS spectra of (a) Si 2p and (b) N 1s for as-deposited films grown with water and ozone. Both depositions at $175^{\circ} \mathrm{C}$. 


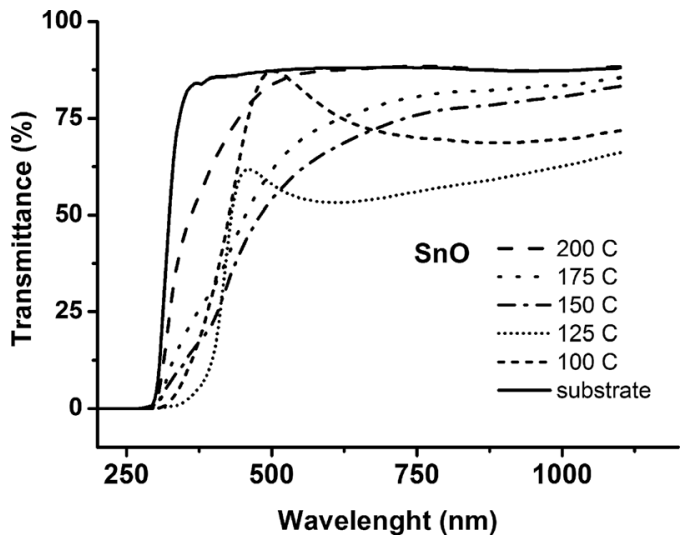

FIG. 10. Transmittance spectra of $\mathrm{SnO}$ films deposited with water on glass at $100-200{ }^{\circ} \mathrm{C}$.

water showed direct band gap values of $2.4-2.6 \mathrm{eV}$ and indirect band gap values of $1.5-1.7 \mathrm{eV}$. The latter is difficult to measure from thin film samples because of the weak optical absorption. Ogo et al. have calculated the indirect band gap of $0.7 \mathrm{eV}$ from diffuse reflectance spectra of bulk $\mathrm{SnO}$ powder. ${ }^{40}$ Their result is in agreement of computational values (PBE0-vdW methodology, $0.67 \mathrm{eV}$ ) reported by Allen et al. who also presented a direct band gap of $2.76 \mathrm{eV}$ for $\mathrm{SnO}^{41}$ Some of the variation probably derives from the $\mathrm{SnO}_{2}$ character in the films grown with water. The films grown with ozone gave no results as the films were colorless, and the transmission spectra did not differ from the spectrum of the substrate.

Conformality, which is one of the greatest assets of ALD, is good for both processes. Conformality was tested by coating $\mathrm{TiO}_{2}$ nanotubes with $\mathrm{SnO}_{\mathrm{x}}$. The results are presented in Fig. 11 which shows $\mathrm{SnO}_{2}\left(-\mathrm{SiO}_{2}\right)$ grown on the $\mathrm{TiO}_{2}$ nanotubes (aspect ratio 1:15) forming coaxial nanotubular structure. The photoactivity and electrical conductivity of the films were tested with $\mathrm{I}-\mathrm{V}$ measurements. The plots from $\mathrm{I}-\mathrm{V}$ measurements of $\mathrm{ITO} / \mathrm{TiO}_{2} / \mathrm{SnO}_{\mathrm{x}}$ nanostructures are shown in Fig. 12. Clear photoactive behavior is not perceived, but some differences between the plots measured in dark and light can be seen. The current densities are higher in the samples grown with the water process than with the

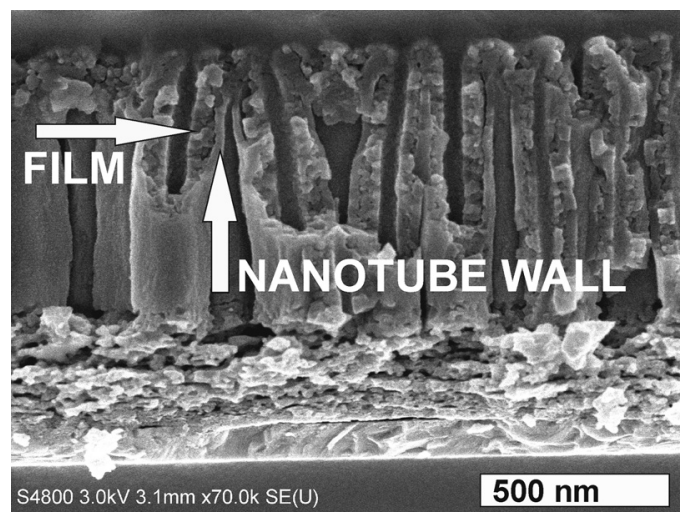

FIG. 11. Cross-section FESEM image of $\mathrm{SnO}_{2}\left(-\mathrm{SiO}_{2}\right)$ deposited conformally in $\mathrm{TiO}_{2}$ nanostructure by ALD. Film deposited with the ozone process for 6000 cycles at $175^{\circ} \mathrm{C}$.

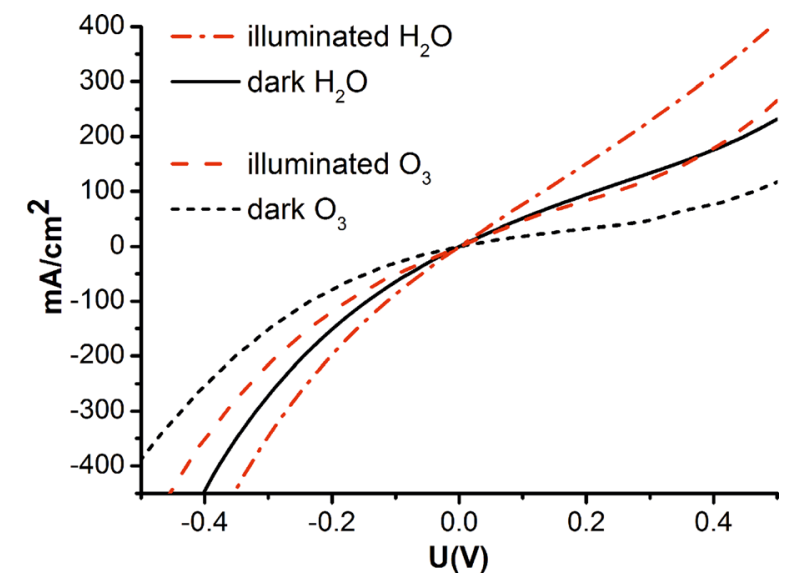

FIG. 12. (Color online) I-V plots measured through the $\mathrm{ITO} / \mathrm{TiO}_{2} / \mathrm{SnO}_{\mathrm{x}}$ samples. Samples are measured illuminated and in dark.

ozone process, in dark and irradiated alike, therefore proving that the electrical conductivity of the films grown with water is higher. The lower conductivity of the films grown with ozone process is likely an effect of the silicon incorporated in the films. The irradiation as a whole increases the current densities in the samples grown with both processes.

\section{SUMMARY AND CONCLUSIONS}

Tin(II)oxide and tin(IV)oxide were deposited by ALD at $80-250{ }^{\circ} \mathrm{C}$ with bis[bis(trimethylsilyl)amino]tin(II) and $\mathrm{H}_{2} \mathrm{O}$ or $\mathrm{O}_{3}$ as the reactants. For ozone process, ALD windows were found at the temperature ranges of $80-100^{\circ} \mathrm{C}$ and $125-200^{\circ} \mathrm{C}$. The film growth rate was low with both oxygen sources, $0.05-0.18 \AA$ /cycle for water and $0.05-0.11 \AA /$ cycle for ozone. With water, the film growth slows down as a function of deposition temperature, which is likely a result of a reaction byproduct, HMDS, that hinders the adsorption of tin precursor. HMDS is oxidized by ozone, therefore incorporating silicon in the film in ozone process, which affects the crystallization and conductivity of the films. Saturation of growth rates was observed for both water and ozone processes after $2 \mathrm{~s}$ pulse lengths. With tin precursor, no clear saturation was observed although the growth rate did remain the same between 2 and $4 \mathrm{~s}$. Films grown with water were crystalline, but films grown with ozone were amorphous. The as-deposited films were all nonconductive. Amorphous and nonconductive nature of the films deposited with ozone derives from silicon oxide that is incorporated in the film during deposition. In FESEM images and AFM measurements, some grains were found in films grown with water deposited at $150-200^{\circ} \mathrm{C}$ while all the films grown with ozone were smooth. This behavior was independent of thickness of the films. The tin in the films grown with ozone was $\mathrm{SnO}_{2}$ while that of the films grown with water was a mixture of $\mathrm{SnO}$ and $\mathrm{SnO}_{2}$. In addition to silicon, XPS also showed some residual nitrogen in the films from the precursor. The demonstrated ALD process was used to coat anodized nanotubular titanium dioxide structure to prepare coaxial nanotubes and a good conformal growth was confirmed. I-V measurements of the as-deposited coaxial nanotubular 
structures showed higher current densities for films grown with water process compared to films grown with ozone process.

\section{ACKNOWLEDGMENT}

Financial support from the Finnish Centre of Excellence in Atomic Layer Deposition (Academy of Finland) is gratefully acknowledged.

${ }^{1}$ S. Yang, Y. Hou, J. Xing, B. Zhang, F. Tian, X. H. Yang, and H. G. Yang, Chem. Eur. J. 19, 9366 (2013).

${ }^{2}$ C. Kilic and A. Zunger, Phys. Rev. Lett. 88, 095501 (2002).

${ }^{3}$ K. Tennakone, G. R. R. A. Kumara, I. R. M. Kottegoda, and V. P. S. Perera, Chem. Commun. 15 (1999).

${ }^{4}$ H. Ohta and H. Hosono, Mater. Today 7, 42 (2004).

${ }^{5}$ E. Comini, G. Faglia, G. Sberveglieri, Z. Pan, and Z. L. Wang, Appl. Phys. Lett. 81, 1869 (2002).

${ }^{6}$ S. Moon, C. Lee, M. Miyamoto, and Y. Kimura, J. Polym. Sci. A 38, 1673 (2000).

${ }^{7}$ M. Batzill and U. Diebold, Prog. Surf. Sci. 79, 47 (2005).

${ }^{8}$ J. A. Caraveo-Frescas, P. K. Nayak, H. A. Al-Jawhari, D. B. Granato, U. Schwingenschlögl, and H. N. Alshareef, ACS Nano 7, 5160 (2013).

${ }^{9}$ K. Nomura, T. Kamiya, and H. Hosono, Adv. Mater. 23, 3431 (2011).

${ }^{10}$ D. Jadsadapattarakul, C. Euvananont, C. Thanachayanont, J. Nukeaw, and T. Sooknoi, Ceram. Int. 34, 1051 (2008).

${ }^{11}$ A. M. B. van Mol, Y. Chae, A. H. McDaniel, and M. D. Allendorf, Thin Solid Films 502, 72 (2006).

${ }^{12}$ R. P. Howson, H. Barankova, and A. G. Spencer, Thin Solid Films 196, 315 (1991).

${ }^{13}$ H. Yabuta, N. Kaji, R. Hayashi, H. Kumomi, K. Nomura, T. Kamiya, M. Hiran, and H. Hosono, Appl. Phys. Lett. 97, 072111 (2010).

${ }^{14}$ S.-C. Lee, J.-H. Lee, T.-S. Oh, and Y.-H. Kim, Sol. Energy Mater. Sol. Cells 75, 481 (2003).

${ }^{15}$ L. Y. Liang, Z. M. Liu, H. T. Cao, and X. Q. Pan, ACS Appl. Mater. Interfaces 2, 1060 (2010)

${ }^{16}$ V. Miikkulainen, M. Leskelä, M. Ritala, and R. Puurunen, J. Appl. Phys. 113, 021301 (2013).

${ }^{17}$ A. Tarre, A. Rosental, A. Aidla, J. Aarik, J. Sundqvist, and A. Hårsta, Vacuum 67, 571 (2002).
${ }^{18}$ J. Sundqvist, M. Ottosson, and A. Hårsta, Chem. Vap. Deposition 10, 77 (2004).

${ }^{19}$ J. Elam, D. Baker, A. Hryn, A. Martinson, M. Pellin, and J. Hupp, J. Vac. Sci. Technol. A 26, 244 (2008).

${ }^{20}$ J. Heo, A. Hock, and R. Gordon, Chem. Mater. 22, 4964 (2010).

${ }^{21}$ C. Marichy, N. Donato, M.-G. Willinger, M. Latino, D. Karpinsky, S.-H. Yu, G. Neri, and N. Pinna, Adv. Funct. Mater. 21, 658 (2011).

${ }^{22}$ E. J. Warner, F. Johnson, S. A. Campbell, and W. L. Gladfelter, J. Vac. Sci. Technol. A 33, 021517 (2015).

${ }^{23}$ D. V. Nazarov et al., J. Vac. Sci. Technol., A 35, 01B137 (2017).

${ }^{24}$ J. H. Han, Y. J. Chung, B. K. Park, S. K. Kim, H.-S. Kim, C. G. Kim, and T.-M. Chung, Chem. Mater. 26, 6088 (2014).

${ }^{25}$ M. Mullings, C. Hagglund, and S. Bent, J. Vac. Sci. Technol., A 31, 061503 (2013).

${ }^{26}$ D. V. Nazarov, N. P. Bobrysheva, O. M. Osmolovskaya, M. G. Osmolovsky, and V. M. Smirnov, Rev. Adv. Mater. Sci. 40, 262 (2015), available at http://www.ipme.ru/e-journals/RAMS/no_34015/07_34015_ nazarov.html.

${ }^{27}$ G. Choi, L. Satyanarayana, and J. Park, Appl. Surf. Sci. 252, 7878 (2006).

${ }^{28}$ S. Kim, D.-H. Kim, and S.-H. Hong, J. Cryst. Growth 348, 15 (2012).

${ }^{29}$ B. K. Lee et al., Mater. Res. Bull. 47, 3052 (2012).

${ }^{30}$ J. Tupala, M. Kemell, E. Härkönen, M. Ritala, and M. Leskelä, Nanotechnology 23, 125707 (2012).

${ }^{31}$ R. A. Waldo, Microbeam Analysis (San Francisco Press, San Francisco, CA, 1988).

${ }^{32}$ M. Sreemany and S. Sen, Mater. Chem. Phys. 83, 169 (2004).

${ }^{33}$ R. Swanepoel, J. Phys. E: Sci. Instrum. 16, 1214 (1983).

${ }^{34}$ W. Xia, H. Wang, X. Zeng, J. Han, J. Zhu, M. Zhou, and S. Wu, Cryst. Eng. Commun. 16, 6841 (2014).

${ }^{35}$ L. Crowe and L. M. Tolbert, Langmuir 24, 8541 (2008).

${ }^{36}$ J. Aarik, A. Aidla, H. Mändar, and V. Sammelselg, J. Cryst. Growth 220, 531 (2000).

37"NIST X-ray Photoelectron Spectroscopy Database," http://srdata.nist.gov/xps/

${ }^{38}$ J. Geurts, S. Rau, W. Richter, and F. J. Schmitte, Thin Solid Films 121, 217 (1984).

${ }^{39}$ A. Roine, HSC-Chemistry for Windows 6.12, Outotec Research Oy, 2007.

${ }^{40}$ Y. Ogo, H. Hiramatsu, K. Nomura, H. Yanagi, T. Kamiya, M. Hirano, and H. Hosono, Appl. Phys. Lett. 93, 032113 (2008).

${ }^{41}$ J. P. Allen, D. O. Scanlon, L. F. J. Piper, and G. W. Watson, J. Mater. Chem. C 1, 8194 (2013). 